\title{
COVER ESSAY
}

\section{Lorillard's "Candy Box" ad for Newport cigarettes: is she pregnant?}

\author{
Ronald M Davis, Anne Landman
}

One of the axioms in tobacco control is that today's outrage from the tobacco industry will be eclipsed by tomorrow's. Just when you think you've seen the worst possible transgression by the bad guys, something even worse comes along.

The "outrage" in the spring of 1985 was an advertisement for Newport Lights which featured a pregnant woman, or at least a woman who looked pregnant-very pregnant. The ad is reproduced on the cover of this journal supplement and as a figure in this essay (fig 1). Tobacco industry documents now available on the web shed light on the history of the ad.

Lorillard called the ad "Candy Box" because it shows a young man offering a box of candy to a young woman - a woman with a very protuberant abdomen. According to the Federal Trade Commission (FTC), "The ad ran extensively in April, May and June [of 1985] in many national magazines, including Family Circle, Time, People, National Enquirer, Woman's Day, etc."

Health groups, not surprisingly, were aghast upon seeing the ad. The image "implies that it is all right for pregnant women to smoke and may be unfair and deceptive in violation of FTC regulations," said Matthew Myers, then director of the Coalition on Smoking OR Health (and now executive director of the Campaign for Tobacco-Free Kids). ${ }^{2}$ The Coalition and others asked the FTC to investigate. At the same time, a staff person for the US House of Representatives' subcommittee on health and the environment (then chaired by Congressman Henry Waxman of California) reported that the subcommittee would hold hearings on cigarette advertising and promotion in September or October of that year, and that the Newport ad was already on the agenda. ${ }^{3}$

In an "informal survey of about 100 people" conducted by the coalition, all respondents described the model as appearing pregnant. ${ }^{3}$ But a spokeswoman for Lorillard told the Associated Press that it was all a matter of "poor cropping": "The (uncropped) photograph of the girl shows she has a very tiny waist and tight jeans in that shot." The billowing pink blouse, she said, was the result of the woman leading backwards. The company, however, refused to give the Associated Press the uncropped photograph or the name of the model. ${ }^{2}{ }^{4}$ Walker Merryman, vice president of the Tobacco Institute, characterised as "horse ....." the suggestion that a cigarette company

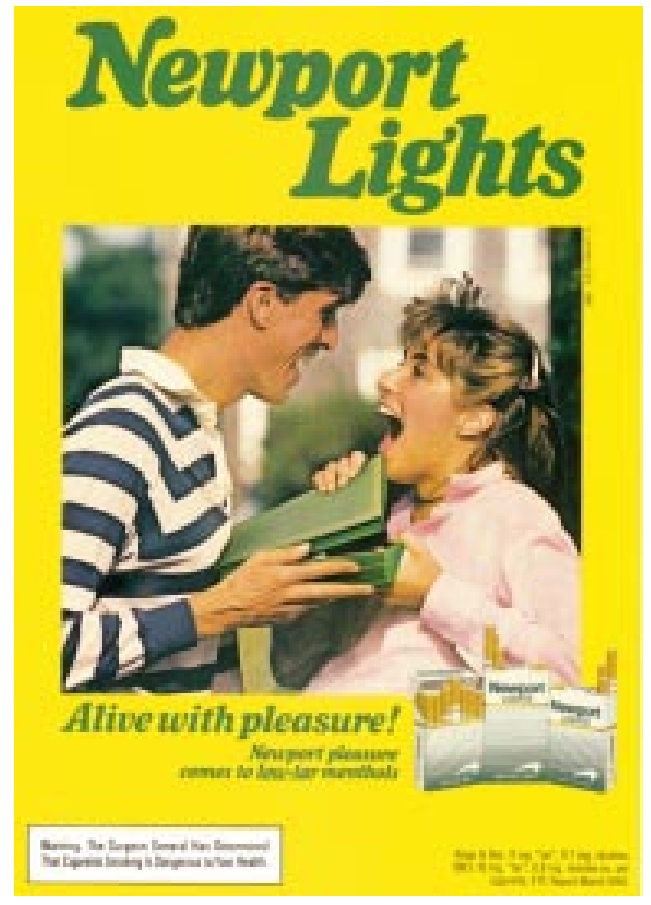

Figure 1 Lorillard's "Candy Box" ad for Newport cigarettes: does she look pregnant?

would use a pregnant woman in its advertising. ${ }^{3}$

\section{The Federal Trade Commission} investigates

On 2 July, the FTC sent letters to Lorillard and its advertising agency (MCA Advertising), stating: "The Commission is concerned that consumers viewing this advertisement may believe that the young lady featured in the advertisement is pregnant." The FTC noted that the ad may violate section 5 of the Federal Trade Commission Act, and it requested all documents, photographs, research, and other information and material pertaining to the ad. ${ }^{5}$

In a detailed letter dated 24 July, Lorillard responded to the commission as follows:

"Neither Lorillard nor MCA conceived that the ad could be interpreted as depicting a pregnant woman; no purpose of Lorillard, MCA or the product is served by the depiction of a pregnant woman, and, indeed, the depiction of a pregnant woman would be a curious, if not bizarre, departure from the theme of any past, present or planned NEWPORT advertising, or from a rational 
Lorillard's formal response to the FTC's investigation of the "Candy Box" ad

November 19, 1985

Ms Judith P Wilkenfeld

Program Advisor for Cigarette Advertising \& Testing

Federal Trade Commission

Washington, DC 20580

Dear Ms Wilkenfeld:

This will acknowledge and respond to Commission letters of July 2, 1985 directed to Lorillard and its advertising agency concerning a Newport Lights advertisement. The ad is designated in our records as "Candy Box".

The Commission letters express the Commission's strong concern that consumers may believe that the woman shown in the ad is pregnant. Please be advised that our reaction, too, is one of concern. Neither Lorillard nor its advertising agency ever thought that the ad could be interpreted as depicting a pregnant woman; it was the intention of neither to depict a pregnant woman; no purpose of Lorillard, its agency or the product is served by the depiction of a pregnant woman; and, indeed, the depiction of a pregnant woman would be a curious, if not bizarre, departure from the theme of any past, present or planned NEWPORT advertising, or from a rational theme for the advertising of any product not closely related to maternity.

It remains only to say that if Candy Box has conveyed to anyone the impression of an ad which includes the depiction of a pregnant woman, it is an impression which was unintended by Lorillard or its advertising agency and one which cannot be reconciled with our promotion of the NEWPORT product. We expend immense effort to ensure that our advertising is not misunderstood; in the future we shall try harder; and the Candy Box ad will not be run again.

We hope that this is responsive to the Commission inquiries on this subject.

Yours very truly,

James R Cherry

Vice President/Deputy General Counsel, Lorillard

theme for the advertising of any product not closely related to maternity." $"$

The company enclosed with its letter the "original photography work for Candy Box ... [which] clearly shows a model who gives no appearance of pregnancy, but is dressed in a loose and billowing blouse and is posed to show an attitude of happy surprise". ${ }^{6}$

Correspondence between the FTC and Lorillard from September to November 1985 suggests that the FTC was ready to close its investigation once it had received a satisfactory letter of explanation from Lorillard which the commission could share with those who petitioned it to investigate the Candy Box ad. Lorillard submitted a draft of a "public" letter to the commission on 13 September. ${ }^{7}$ In a letter dated 7 November, Judith Wilkenfeld of the FTC advised Lorillard that the draft letter, "with few edits", would be "responsive to our needs". 8 She enclosed an edited version of Lorillard's original draft.

On 19 November, Lorillard sent the letter "in final form" to the FTC, but noted the following agreement about dissemination of the letter:

"We understand that the enclosed letter will be made public only by providing a copy to persons or groups who may have petitioned the Commission about the matter, but that there will be no general publication of the letter nor will there be a Commission press conference or release concerning it." $"$

\section{Lorillard expresses "concern," but does not apologise}

The "public" letter ${ }^{10}$ expressed Lorillard's "concern" and promised that the company would "try harder" in the future to ensure that its advertising is not misunderstood. Lorillard, however, did not apologise for the ad (see box).

On 2 December, the FTC sent Lorillard's "public" letter to one of the petitioners, the Association of State and Territorial Health Officials, ${ }^{11}$ and presumably to the other petitioners as well. In its letter to the association, the commission noted that, "In light of Lorillard's response, we have closed our inquiry."

One internal Lorillard document reveals an interesting change in a draft of the "public" letter. The final letter states:

"The Commission letters [to Lorillard and MCA Advertising] express the Commission's strong concern that consumers may believe that the woman shown in the ad is pregnant. Please be advised that our reaction, too, is one of concern."

A document on Lorillard's website ${ }^{12}$ shows the draft letter dated 23 September, with editing marks that downgraded both the FTC and Lorillard's reactions to the ad from "one of shock" to mere "concern". It is unclear who was responsible for those changes.

Congressman Waxman did hold hearings on cigarette advertising and promotion, but not until July and August 1986. Dr Roger Blackwell, a marketing professor at Ohio State University, appeared as a witness for the Tobacco Institute. When asked by Congressman Waxman if the woman in the Candy Box ad appears to be pregnant, he replied: "It is not clear that she is pregnant. She may or may not be." The inquiry continued as follows:

Waxman: "I don't want to argue whether you think she is [pregnant] or not. If someone saw the ad and thought the woman was pregnant, would that violate the industry's code of advertising?"

Blackwell: "I would consider that an unethical thing to state (sic). It seems to me that would be a violation of what should be in the code, if it is not."13

\section{Using (and abusing?) the Freedom of Information Act}

In May 1986, Joe Tye of the Health Advocacy Center in Palo Alto, California submitted a Freedom of Information Act (FOIA) request to the FTC, seeking any information, documents, or other materials in the commission's files pertaining to the Candy Box ad. ${ }^{14}$ In a letter dated 7 July, the FTC granted the request "in part," but the commission withheld some material as exempt from the act because it may have contained "trade secrets and confidential commercial or financial information." 15

The next step in this chain of events is very interesting. On 14 July, John Rupp of Covington \& Burling (a law firm which does substantial work for the tobacco industry) wrote a letter to the deputy general counsel at Lorillard with the following information:

"I spotted a couple of weeks ago a reference to an FOIA request that had been filed by Joe Tye of the Health Advocacy Center concerning Newport Lights advertising. I filed a piggyback request with the FTC to find out what Tye had 
been given. The material that the FTC sent in response to my request, which I submitted on a blind basis through Federal Document Retrieval, is enclosed." 16

This letter is noteworthy on several accounts: (1) it suggests that the tobacco industry's surveillance of activities within the tobacco control community is extensive (where did Rupp spot a reference to Tye's FOIA request?); (2) it shows that the industry acts quickly on the findings of its surveillance (Rupp obtained and forwarded to Lorillard the same FOIA materials that were sent to Tye only seven days earlier); and (3) it shows how the industry likes to cover its tracks, in this case by filing its own FOIA request "on a blind basis" through a third party firm. Aguinaga and Glantz cited examples of FOIA requests submitted to the US Centers for Disease Control and Prevention's Office on Smoking and Health by document retrieval companies. ${ }^{17}$ These requests were always presumed to have originated from the tobacco industry. The Rupp letter ${ }^{16}$ confirms the industry's use of those companies to "anonymise" its FOIA requests to government agencies.

\section{Devious conduct or incredibly sloppy work?}

The FTC dropped its investigation presumably because it was convinced that the model was not pregnant, or at least not noticeably pregnant, based on its examination of uncropped photographs. Accepting that premise, one is left with two possible explanations for the appearance of the woman in the Candy Box ad: (1) Lorillard and/or its advertising agency knew that the model appeared to be pregnant, but still approved the ad because it was "good for business"; or (2) both Lorillard and its advertising agency somehow missed the obvious fact that the model appeared to be pregnant.

In contemplating whether a cigarette company and its advertising agency are indeed capable of inadvertently making such a colossal blunder, it is useful to understand how carefully settings are staged, models are selected, and photographs are chosen for cigarette advertisements. An article in the magazine American Photographer, ${ }^{18}$ which described the photography behind an advertising campaign for Vantage cigarettes, is illuminating. Preshoot planning for the ads began months ahead of the shoot date. For the risky, high action sports depicted in the ads, the "grand-master sensationalist" photographer shot 40 to 50 rolls of special professional quality film each day. Editing sessions in the evening usually yielded 80 "top quality" slides, four or five of which were chosen at headquarters in New York for use in single or double page ads in magazines. Assuming conservatively that the photographer used rolls of film with 24 exposures each (versus 36), about 240 photographs were taken on average to create one final advertisement.

Admittedly the photography for high action Vantage ads is much more involved than the photography for Newport ads in slow action settings. But even if one fourth as many photographs are taken for Newport ads like Candy Box, that still means that about 80 photographs would be taken for one final advertisement. How can ad agency and cigarette company workers pore over 80 photographs for an ad-examining each for colour, lighting, facial expressions, and so onand somehow miss a billowing blouse in the one finally chosen?

The tobacco control advocacy group STAT (Stop Teenage Addiction to Tobacco) scoffs at the notion that mere sloppiness can explain the Candy Box ad:

"Given the tobacco industry's lifelong alignment with slimness, it is doubtful that this photo accidentally 'slipped by' Lorillard's crackerjack ad agency." 19

We thank Richard Pollay for alerting us to the article cited as reference 18 .

1 Federal Trade Commission memorandum from Judith P. Wilkenfeld to Amanda Pedersen and Lee Peeler, Re "Lorillard, File No. 852 3233, Newports (sic) Lights/ Status Report," undated. www.lorillarddocs.com/ getallimg.asp?DOCID $=85624927 / 4928$

2 Uproar over cigarette ad. Associated Press, 29 July 1985. www.lorillarddocs.com/getallimg.asp?DOCID $=85624962$ 4964

3 Colford SW. Newport ad bears scrutiny. Advertising Age, 22 July 1985. www.lorillarddocs.com/getallimg.asp?DOCID July 1985 . Www.lori

4 Cigarette ad debate continues. Associated Press, 29 July 1985. www.lorillarddocs.com/getallimg.asp?DOCID $=85624962 / 4964$

5 Letter from Judith Wilkenfeld and Susan Cohn (Federal Trade Commission) to CH Judge (president, Lorillard), 2 July 1985. www.lorillarddocs.com/getallimg.asp?DOCID $=85624940 / 494$

6 Letter from James R Cherry (vice-president and deputy counsel, Lorillard) to Judith P Wilkenfeld (Federal Trade Commission), 24 July 1985. www.lorillarddocs.com/ getallimg.asp?DOCID =85624965/4967

7 Letter from James R Cherry (vice president and deputy general counsel, Lorillard) to Judith P Wilkenfeld (Federal www.lorillarddocs.

8 Letter from Judith P. Wilkenfeld (Federal Trade Commission) to James R Cherry (vice president and deputy general counsel, Lorillard), 7 November 1985. general counsel, Lorillard), $7 \quad$ November 1985.
www.lorillarddocs.com/getallimg.asp?DOCID $=85624931$

9 Letter from James R Cherry (vice president and deputy general counsel, Lorillard) to Judith P Wilkenfeld (Federal Trade Commission), 19 November 1985. www.lorillarddocs.com/getallimg.asp?DOCID $=85624921$

10 Letter from James R Cherry (vice president and deputy general counsel, Lorillard) to Judith P Wilkenfeld (Federal Trade Commission), 19 November 1985. www.lorillarddocs.com/ getallimg.asp?DOCID $=85624922 / 4923$

11 Letter from Judith P Wilkenfeld (Federal Trade Commission) to George K Degnon (Association of State and Territorial Health Officials), 2 December 1985. www.lorillarddocs.com/getallimg. asp?DOCID $=85624929$

12 Draft 9/13/85. www.lorillarddocs.com/getallimg.asp? DOCID $=85624955 / 4956$

13 Testimony of Roger D Blackwell, hearings before the Subcommittee on Health and the Environment, Committee on Energy and Commerce, US House of Representatives, 99th Congress, 2nd session, 18 July and 1 August 1986, Serial No. 99-167: 708-36,
Government Printing Office, 1987.

14 Letter from Joe B Tye (Health Advocacy Center) to Judith P Wilkenfeld (Federal Trade Commission), 27 May 1986. www.lorillarddocs.com/getallimg.asp?DOCID $=85624912$ www.lori

15 Letter from Alan Proctor (Federal Trade Commission) to Joe B Tye (Health Advocacy Center), 7 July 1986. www.lorillarddocs.com/getallimg. asp?DOCID $=85624915 /$ 4916

16 Letter from John P Rupp (Covington \& Burling) to James R Cherry (vice president and deputy general counsel, Lorillard), 14 July 1986. www.lorillarddocs.com/ getallimg.asp?DOCID $=85624910 / 4911$

17 Aguinaga S, Glantz SA. The use of public records acts to interfere with tobacco control. Tobacco Control 1995; 4:222-30.

18 Kaplan M. Inside advertising: perfect match. A new vantage point lights up smokers' ads. American Photography 1986 (October):100-2.

19 STAT. The tobacco industry's targeting of women $\mathcal{E}$ people of color. The STAT speaker's guide \& slide collection: supplement II. Springfield, Massachusetts: STAT (Stop Teenage Addiction to Tobacco), 1994:13. 